\title{
XANTHOGRANULOMATOUS ORCHITIS: AN UNUSUAL FORM OF TESTICULAR ABSCESS
}

\author{
Durairaj Balaji1 ${ }^{1}$ Alankrith Ramesh Kashyap ${ }^{2}$, Arun Prasanth ${ }^{3}$, Soundrapandian Floret ${ }^{4}$ \\ ${ }^{1}$ Assistant Professor, Department of General Surgery, SRM Medical College Hospital and Research Centre, Chennai. \\ 2 Post Graduate, Department of General Surgery, SRM Medical College Hospital and Research Centre, Chennai. \\ ${ }^{3}$ Post Graduate, Department of General Surgery, SRM Medical College Hospital and Research Centre, Chennai. \\ ${ }^{4}$ Professor, Department of General Surgery, SRM Medical College Hospital and Research Centre, Chennai.
}

\begin{abstract}
Testicular abscess with reactive hydrocele can be challenging to differentiate from malignancy or epididymo-orchitis. We present a case of 60 year male with complaint of swelling right scrotum for 6 months without any other symptoms and comorbidities. USG impression heterogeneous enlarged right testis suggestive of right testicular abscess with fluid collection in tunica vaginalis sac? Pyocele; proceeded with right high orchidectomy in suspicion of malignancy per-operatively cord was thickened. On examining the specimen gross hydrocele was found and on incising testis frank pus extruded, HPE-acute on chronic xanthogranulomatous epididymo-orchitis with foreign body giant cell reaction testis shows atrophic changes. Epididymo-orchitis or testicular abscess or pyocele usually presents with fever and pain scrotum. In our case, it was asymptomatic and chronic.
\end{abstract}

\section{KEYWORDS}

Xanthogranulomatous Orchitis, Testicular Abscess.

HOW TO CITE THIS ARTICLE: Balaji D, Kashyap AR, Prasanth A, et al. Xanthogranulomatous orchitis: an unusual form of testicular abscess. J. Evolution Med. Dent. Sci. 2016;5(42):2647-2648, DOI: 10.14260/jemds/2016/619

\section{INTRODUCTION}

Testicular abscess is a rare enthralling surgical entity, a chronic complication of a common disease-epididymo-orchitis, presenting as an acute or sub-acute scrotum with an incidence rate less than 1 per 1000 males per year; affecting $4-5 \%$ of clinically diagnosed males with severe epididymo-orchitis.[1,2] Testicular abscess is mainly a result of bacterial epididymoorchitis, especially in sexually active young individuals, but may also be due to testicular insult such as torsion or trauma. ${ }^{[2]}$ Among all the causes of testicular abscess, xanthogranulomatous orchitis has a unique standpoint in terms of rarity, as only 14 cases (Incidence rate $0.6 \%$ ) have been reported by far in literature.[3]

\section{CASE REPORT}

A 60-year-old man presented with swelling on right side of his scrotum since 6 months. He did not have this swelling before and it progressively grew in a matter of few months to its present size. No history of pain in scrotum, burning urination, pain abdomen, fever, trauma, recent sexual activity. He was diagnosed with hypertension 10 days back and on regular medication. He is not a diabetic. No history of Pulmonary TB. He is not involved in drug abuse habits, smoking or alcohol intake. Patient is able to carry out his daily activity. There is no loss of weight. His systemic examination was normal and there was no lymphadenopathy. His right testis was examined which revealed a swelling within the testis of $8 \times 8 \mathrm{~cm}$, globular shape, no warmth and tenderness, variable firm-to-hard consistency with loss of testicular sensation. Skin over the scrotum was normal. Left testis was normal.

Financial or Other, Competing Interest: None.

Submission 11-04-2016, Peer Review 05-05-2016,

Acceptance 11-05-2016, Published 26-05-2016.

Corresponding Author:

Dr. Alankrith Ramesh Kashyap,

Room 303, PG Medical Gents Hostel,

SRM College Hospital \& Research Centre,

SRM Nagar, Kattankulathur,

Chennai-603203.

E-mail: koolchant@gmail.com

DOI: $10.14260 /$ jemds/2016/619
A provisional diagnosis of right-sided chronic hydrocele was made. But a suspicion to rule out right testicular tumour was kept in mind. He was sent for an ultrasonography of abdomen and scrotum and his blood and urine examination was done. Total count: 8600 cells/cu.mm (Normal 4000-11000 cells/cu.mm).

\section{Ultrasonography of Abdomen and Scrotum}

Mild prostatomegaly. Heterogeneous enlarged right testis with infected fluid collection within tunica vaginalis sac? Pyocele. A diagnosis of right pyo-orchium with reactive hydrocele was made and owing to its severity high orchidectomy under broad-spectrum antimicrobial coverage was done.

\section{Intra-Operative Findings}

Thickened cord structures, hard right testis with reactive hydrocele [Figure 1,2]. Cut section of right testis showed 20 $\mathrm{mL}$ of pus [Figure 3].

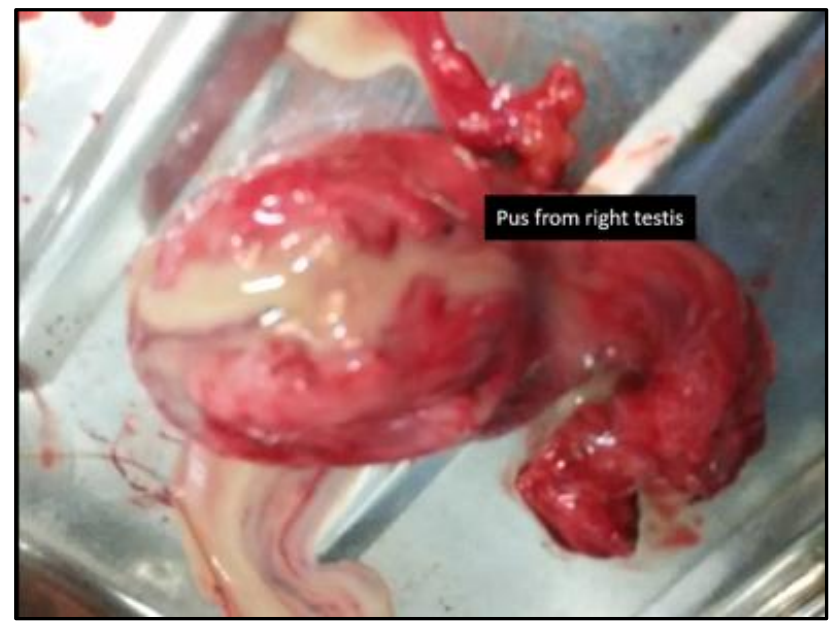

Fig. 1 


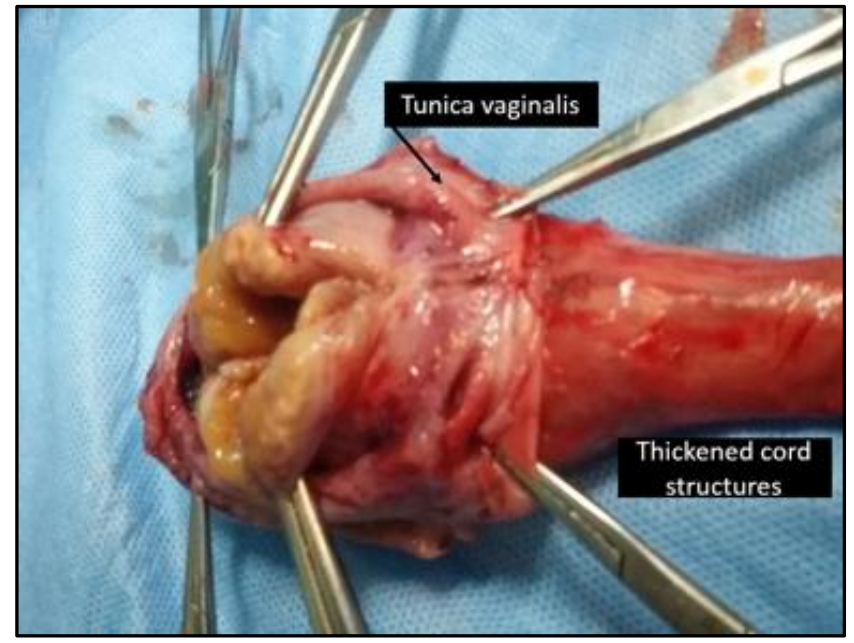

Fig. 2

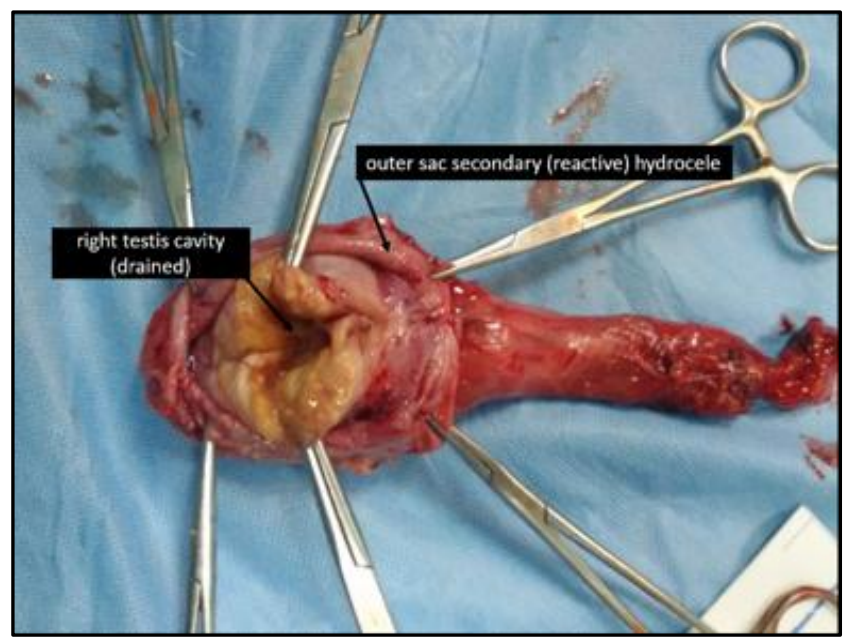

Fig. 3

\section{HISTOPATHOLOGY REPORT}

\section{Specimen}

Right testis with cord.

\section{Impression}

Acute on chronic xanthogranulomatous epididymo-orchitis with foreign body giant cell reaction. Testis shows atrophic changes. Patient's post-operative recovery was uneventful.

\section{DISCUSSION}

Epididymo-orchitis is a common surgical entity encountered with an incidence rate of $45 \%$, which presents with features of acute scrotum. ${ }^{[4]}$ Epididymitis in men aged more than 35 years is a result of repeated urinary tract infections, mostly Gram negative enteric bacteria associated with instrumentation of genitourinary tract which when partially or untreated can develop into a rare complication of testicular abscess.[5,6]
Acute epididymo-orchitis when left untreated or suboptimally treated can cause the pathogen to infect the testis via vas deferens in a retrograde fashion.[1] Other risk factors associated with testicular abscess include viral infections like mumps, influenza, testicular trauma, chemicals, tuberculosis, fungal infection. $[1,4,7]$

Testicular abscess, especially bacterial mainly presents with acute painful scrotum and fever.[8] Ultrasound scrotum in testicular abscess demonstrates hypoechoic lesion within testis with low-level echoes and shaggy margins, absent vascularity and increased peripheral hyperaemia, warranting percutaneous or open drainage procedures.[6,8]

On the other hand, Xanthogranulomatous orchitis with a very low incidence rate of $0.6-1.4 \%$ is more common in elderly and presents with almost unremarkable clinical features, thus mimicking testicular tumours.[3] Ultrasonogram too shows regular features as that of any other testicular abscess. [3] Pathogenesis has remained nebulous, though tissue destruction is a known feature of this bizarre disease that surgical removal of the testis remains the treatment of choice. [3] Histopathology shows foamy macrophages, minimal plasma cells, absence of caseous necrosis or epithelioid granulomas and no increase in serum tumour markers. ${ }^{[3]}$

\section{CONCLUSION}

Xanthogranulomatous orchitis is a rare subset of testicular abscess, which itself is a rare complication of epididymoorchitis. So better research is needed to unravel the mystery of this diagnostic conundrum; as of yet high orchidectomy with good anti-microbial coverage remains the best and safest modality for satisfactory patient management.

\section{REFERENCES}

1. Biswas Subikas, Basu Gandhari. Causes \& management of testicular abscess: findings of a study on eleven patients. IOSR-JDMS 2013;9(1):26-30.

2. Suhani, Ali Shadan, Choudhari Vikas, et al. Case report: testicular abscess: an uncommon complication of a common entity. FCM 2014;1(1):12-3.

3. Al-Said Sami, Ali Ammar, Alobaidy Abdul Kader, et al. Xanthogranulomatous orchitis: review of the published work and report of one case. International Journal of Urology 2007;14(5):452-4.

4. Kavoussi LR, Partin AW, Novick AC, et al. Campbell-walsh urology. Elsevier Saunders 2012;10 th edn:3117-18.

5. Tanagho Emil A, McAninch Jack W. Smith's general urology. McGraw Hill 2008;17th edn:p 238.

6. Levis Joel T, Garmel Gus M. Clinical emergency medicine casebook. Cambridge University Press 2009;p 184.

7. Potts Jeannette M. Genitourinary pain and inflammation: diagnosis and management. Humana Press 2008; $1^{\text {st }}$ edn:p 143.

8. Fulgham Pat F, Gilbert Bruce R. Practical urological ultrasound. Humana Press 2013;1 ${ }^{\text {st }}$ edn:p 93. 